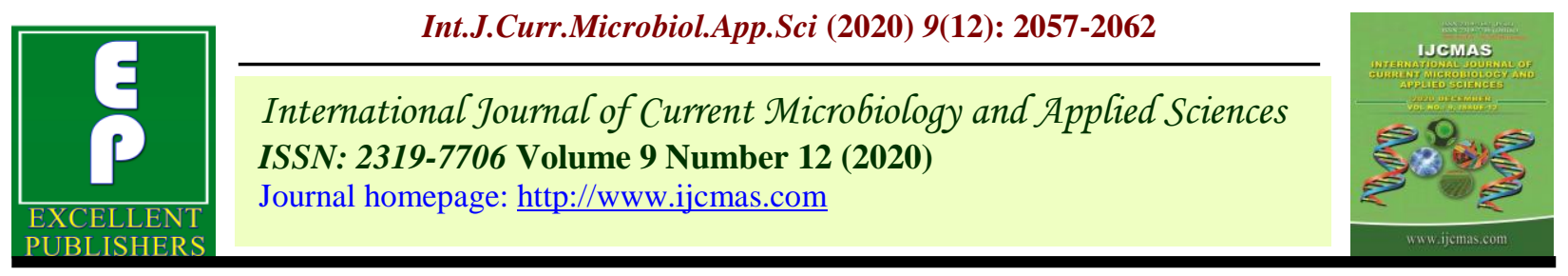

Original Research Article

https://doi.org/10.20546/ijcmas.2020.912.242

\title{
Effect of Different Fly Ash and Nitrogen Levels on Growth and Yield of Indian Mustard (Brassica juncea L.)
}

\author{
Harmohan Singh, Balwinder Singh Dhillon* and Mandeep Kaur
}

College of Agriculture, Guru Kashi University, Talwandi Sabo, Punjab, India

*Corresponding author

\begin{tabular}{|l|}
\hline Key w o r d s \\
Indian mustard, Fly \\
ash, Growth, \\
Nitrogen and seed \\
yield
\end{tabular}

The field experiment entitled Effect of different levels of fly ash and nitrogen on growth and yield in Indian mustard (Brassica juncea L.) was conducted at the experimental farm of the University College of Agriculture, Guru Kashi University, Talwandi Sabo during rabi season 2018. The experiment was conducted in split plot design with combination of two levels of fly ash (control, fly ash@10 t/ha) in main plots and four levels of nitrogen $(0,75,100$ and $125 \mathrm{~kg}$ $\mathrm{N} / \mathrm{ha}$ ) in sub plots, replicated three times. Application of nitrogen@125 kg $\mathrm{N} /$ ha significantly increased the plant height $(227 \mathrm{~cm})$, leaf area index $(4.72)$, no. of seed/siliqua (604) as compared to other levels of nitrogen. Significant interaction effect between fly ash and nitrogen was observed for number of siliquae per plant. Application of fly ash @ 10t/ha with $125 \mathrm{~kg} \mathrm{~N} / \mathrm{ha}$ recorded higher seed yield. The results showed that application of $10 \mathrm{t} / \mathrm{ha}$ fly ash gave significantly higher seed yield (20.8 q/ha) and increase was $11.8 \%$ over control. The application on nitrogen @ $125 \mathrm{Kg} / \mathrm{ha}$ increased the seed yield with $20.8,11.7$ and $5.9 \%$ increase over control, 75 and $100 \mathrm{~kg} \mathrm{~N} / \mathrm{ha}$, respectively.

\section{Introduction}

Mustard (Brassica juncea L.) is an essential edible oil seed crop of the world and rank third after soybean and oil-palm. It belongs to the family Brassicaceae. In India, oilseeds comprise the second largest agriculture commodity after cereals; accounting for about $5 \%$ of gross national product and $10 \%$ of the value of all agriculture products. Raya is valued for its intense flavors and healing properties. This plant is cultivated mainly as an oil crop. All over the world, mustard is used for its delicious flavor and preservative value and the seeds are used largely for tempering food in recent times. It has been explored for its biodiesel potential. The oil content varies from 38 to $50 \%$. Its tender leaves, tender stem with leaves are used for cooking (Saag).

Fly ash, a by- product of the thermal power plants. The use of coal is becoming not only a problem for pollution of environment, but 
also for storage. Therefore investigation is needed for it use in crop production. It contains oxides, hydroxides, caronates, silicates, and sulfates of calcium, iron, aluminum and other metals in trace amount (Thanunathan et al., 2001). The mineralogical, physical, and chemical properties of fly ash depend on the nature of the parent coal, conditions of the combustion, type of emission control devices and storage and handling methods. The earlier studies have revealed the beneficial effect of fly ash in combination with recommended dose of fertilizers on seed yield of sunflower (Jambagi et al., 1995). Presence of essential plant nutrients such as $\mathrm{N}, \mathrm{P}, \mathrm{K}, \mathrm{Ca}, \mathrm{Mg}, \mathrm{S}$ and micronutrients make it a source of plant nutrients and increase yield of several crops by $20-25 \%$ with high nutritional value and found beneficial for soil and crop when it was applied in minimal quantity.

Nitrogen is an essential major nutrient for increasing the productivity of Raya (Brassica juncea L.) to low yield. Lower doses of nitrogen lead to lower yield, where as excessive dose of nitrogen lead to attack of diseases and insects. Nitrogen plays an important role in oilseed production because of the nutrients requirement of oilseeds, in general is high. The $\mathrm{P}$ compounds (ADP and ATP) in fact as energy currency within the plant. It plays a vital role in plant metabolism. Narang and Singh (1985) observed linear increase in various growth parameters of Indian mustard with increasing doses of $\mathrm{N}$ from $0-150 \mathrm{~kg} / \mathrm{ha}$ in sandy loam soil. Keeping, the above considerations in view, the present study was planned to work out the appropriate dose of nitrogen, where applied with different levels of fly ash.

\section{Materials and Methods}

The present investigation entitled "Effect of different fly ash and nitrogen levels on growth and yield of Indian mustard" was conducted at the research farm, Guru Kashi University, Talwandi Sabo (Bathinda) during Rabi 201819. Talwandi Sabo Bathinda is located at $29^{\circ} 57 \mathrm{~N}$ latitude and $75^{\circ} 7 \mathrm{E}$ longitude at height of 213 meters above the mean sea level. It is characterized by semi- arid climate, where both summers and winters are acute. A maximum temperature of about $45^{\circ}$ is not uncommon during summer, while freezing temperature accompany by frost happening may be in the months of December and January. The monsoon normally starts from the first week of July. The composite soil sample of $0-15 \mathrm{~cm}$ depth was analyzed for $\mathrm{pH}, \mathrm{EC}, \mathrm{OC}$ and available nutrients to know their status before sowing of crop. The soil of experimental field was low in nitrogen, medium in nitrogen and also medium in potassium.

\section{Results and Discussion}

The data related to plant height have been presented in Table 1. Perusal of data showed that application of fly ash does not show significant influence on plant height of raya. Application of nitrogen significantly influenced the plant height at maturity. Amongst the different nitrogen levels, the maximum plant height $(227 \mathrm{~cm})$ was observed with the application of $125 \mathrm{~kg} \mathrm{~N} / \mathrm{ha}$ which was significantly higher over the control but it was statically at par with treatment $100 \mathrm{~kg}$ N/ha. This might be due to increased nitrogen supply to plants resulted in more photosynthetic activities. Bhari et al., (2000) reported that application of $120 \mathrm{~kg} \mathrm{~N} / \mathrm{ha}$ significantly increased the plant height of mustard. Application of fly ash and interaction effect between fly and nitrogen levels on plant height of Indian mustard was also found to be non-significant effect.

Application of fly ash @ 10t/ha significantly increased the dry matter accumulation of 
Indian mustard than control. The maximum dry matter accumulation (75.5 q/ha) was recorded in fly ash (10 t/ha). Amongst the different nitrogen levels, significantly higher dry matter accumulation (79.3 q/ha) was observed with the application of $125 \mathrm{~kg} \mathrm{~N} / \mathrm{ha}$ which was higher as compared to other nitrogen levels. Kuchanwar and Matte (1997) reported that application of fly ash (10 t/ha) increased the growth attributes. Similarly, Ram et al., (2013) reported that application of $120 \mathrm{~kg}$ N/ha significantly higher dry matter accumulation in Indian mustard. The interaction effect between fly ash and nitrogen levels on dry matter accumulation was non significant. Application of Fly ash and nitrogen significantly influenced the leaf area index at 120 DAS. Application of fly ash (10 t/ha) recorded the maximum leaf area index (4.49) than control. Amongst the different nitrogen levels, the maximum leaf area index (4.72) was observed with the application of $125 \mathrm{~kg} \mathrm{~N} / \mathrm{ha}$ which was significantly higher as compared to other nitrogen levels. This might be due to increasing nitrogen supply to plants resulted in increase in no. of branches/plant. Bhari et al., (2000) reported that application of $120 \mathrm{~kg}$ N/ha significantly increased the leaf area index of mustard. Similarly, Kene et al., (1991) reported that application of fly ash $10 \%$ significantly increased the plant height of sunflower. The interaction effect between fly and nitrogen levels on leaf area index of Indian mustard was also found to be nonsignificant effect. The data related to no. of branches have been given in Table 1 . Application of nitrogen significantly influenced the no. of branches at maturity. Amongst the different nitrogen levels, the maximum no. of branches (20.8) was observed with the application of $125 \mathrm{~kg} \mathrm{~N} / \mathrm{ha}$ which was significantly higher over control. This might be due to increasing nitrogen supply to plants resulted in more photosynthetic activities. Singh and Singh
(2002) reported that application of $120 \mathrm{~kg}$ $\mathrm{N} /$ ha significantly increased the no. of branches of mustard. Application of fly ash and interaction effect between fly and nitrogen levels on no. of branches of Indian mustard was also found to be non-significant effect.

Data on no. of siliqua/plant have been presented in Table 2. Application of fly ash on no. siliqua/plant of Indian mustard was also found to be non-significant effect. Amongst the different nitrogen levels, significantly higher no. of siliqua/plant (604) was observed with the application of $125 \mathrm{~kg}$ $\mathrm{N} / \mathrm{ha}$ which was significantly higher as compared to other nitrogen levels. The interaction effect between fly ash and nitrogen levels on no. of siliqua/plant was also significant. The significantly higher no. of siliqua/plant (622) was recorded with fly ash (10 t/ha) in combination with $\mathrm{N} 125 \mathrm{~kg} / \mathrm{ha}$ as compared to other combinations. This may be increase with increase in no. of branches/plant, leaf area index and better nutrient supply to plants. Sharawat et al., (2002) reported that application of N120 $\mathrm{kg} / \mathrm{ha}$ increased the number of siliqua per plant as compared to other nitrogen levels in mustard.

Application of Fly ash and nitrogen significantly influenced the no. of seeds/siliqua at maturity. Application of fly ash (10 t/ha) recorded the maximum no. of seeds/siliqua (12.2) than control. Amongst the different nitrogen levels, the maximum no. of seeds/siliqua (12.8) was observed with the application of $125 \mathrm{~kg} \mathrm{~N} / \mathrm{ha}$ which was significantly higher as compared to other nitrogen levels. This might be due to increasing nitrogen supply to plants resulted in increase in no. of seeds/siliqua. Bhari et. $a l$., (2000) reported that application of $120 \mathrm{~kg}$ $\mathrm{N} /$ ha significantly increased the no. of seeds/siliqua of mustard. Similarly, 
Thanunathan et al., (2001) reported that the fly ash application in combination with organic and inorganic fertilizers has resulted higher number of seed/capsules when fly ash was applied at 30 t/ha along with FYM. The interaction effect between fly and nitrogen levels on no. of seeds/siliqua of Indian mustard was also found to be non-significant effect.

The data related to 1000 seeds weight given in Table 2 clearly shows non-significant results in fly ash levels. Amongst the different nitrogen levels, the maximum test weight $(5.36 \mathrm{gm})$ was observed with the application of $125 \mathrm{~kg} \mathrm{~N} / \mathrm{ha}$ which was significantly higher as compared to other nitrogen levels. This might be due to increasing nitrogen supply to plants resulted increase in test weight. Reager et al., (2006) reported that application of $\mathrm{N} 110 \mathrm{~kg} / \mathrm{ha}$ significantly increased the 1000 seed weight of mustard. The interaction effect between fly and nitrogen levels on test weight of Indian mustard was also found to be nonsignificant effect.

Table.1 Effect of different fly ash and nitrogen levels on growth parameters of Indian mustard

\begin{tabular}{|c|c|c|c|c|}
\hline Treatments & $\begin{array}{c}\text { Plant } \\
\text { height }(\mathbf{c m})\end{array}$ & $\begin{array}{c}\text { Dry matter } \\
\text { accumulation } \\
(\mathbf{q} / \mathbf{h a})\end{array}$ & $\begin{array}{l}\text { Leaf area } \\
\text { index }(\mathrm{cm})\end{array}$ & $\begin{array}{l}\text { No. branches } \\
\text { per plant }\end{array}$ \\
\hline \multicolumn{5}{|c|}{ Fly ash levels (t/ha) } \\
\hline $\mathbf{0}$ & 209 & 70.3 & 3.74 & 15.0 \\
\hline 10 & 213 & 75.5 & 4.49 & 17.0 \\
\hline LSD at $\mathrm{P}=0.5 \%$ & NS & NS & 0.12 & NS \\
\hline \multicolumn{5}{|c|}{ Nitrogen levels (kg/ha) } \\
\hline $\mathbf{0}$ & 187 & 66.0 & 3.45 & 11.5 \\
\hline 75 & 211 & 71.1 & 3.84 & 14.6 \\
\hline 100 & 224 & 75.2 & 4.45 & 18.5 \\
\hline 125 & 227 & 79.3 & 4.72 & 20.8 \\
\hline LSD at $\mathrm{P}=0.5 \%$ & 5.5 & NS & NS & 1.7 \\
\hline & & & & \\
\hline
\end{tabular}

Table.2 Effect of different fly ash and nitrogen levels on yield parameters of Indian mustard

\begin{tabular}{|c|c|c|c|}
\hline Treatments & No. of siliqua/plant & No. seeds per pod & Test weight (g) \\
\hline \multicolumn{4}{|c|}{ Fly ash levels $(\mathrm{t} / \mathrm{ha})$} \\
\hline $\mathbf{0}$ & 482 & 11.1 & 5.12 \\
\hline 10 & 513 & 12.2 & 5.13 \\
\hline LSD at $\mathrm{P}=0.5 \%$ & NS & 0.2 & NS \\
\hline \multicolumn{4}{|c|}{ Nitrogen levels (kg/ha) } \\
\hline $\mathbf{0}$ & 293 & 10.5 & 4.87 \\
\hline 75 & 529 & 11.4 & 5.09 \\
\hline 100 & 564 & 12.5 & 5.19 \\
\hline 125 & 604 & 12.8 & 5.36 \\
\hline LSD at $\mathrm{P}=0.5 \%$ & 16.8 & NS & 0.07 \\
\hline
\end{tabular}


Table.3 Effect of different fly ash and nitrogen levels on productivity of Indian mustard

\begin{tabular}{|c|c|c|c|}
\hline Treatments & $\begin{array}{l}\text { Seed yield } \\
\text { (q/ha) }\end{array}$ & $\begin{array}{l}\text { Stover yield } \\
(\mathrm{q} / \mathrm{ha})\end{array}$ & $\begin{array}{c}\text { Harvest index } \\
(\%)\end{array}$ \\
\hline \multicolumn{4}{|c|}{ Fly ash levels $(\mathrm{t} / \mathrm{ha})$} \\
\hline $\mathbf{0}$ & 18.6 & 68.8 & 21.2 \\
\hline 10 & 20.8 & 74.2 & 21.7 \\
\hline LSD at $0.5 \%$ & 1.0 & 4.4 & NS \\
\hline \multicolumn{4}{|c|}{ Nitrogen levels (kg/ha) } \\
\hline $\mathbf{0}$ & 16.2 & 64.9 & 20.0 \\
\hline 75 & 19.0 & 69.7 & 21.4 \\
\hline 100 & 20.1 & 73.5 & 21.3 \\
\hline 125 & 23.6 & 77.9 & 23.1 \\
\hline LSD at $0.5 \%$ & 4.3 & 2.6 & NS \\
\hline
\end{tabular}

Application of Fly ash and nitrogen significantly influenced the seed yield of Indian mustard. Application of fly ash (10 $\mathrm{t} / \mathrm{ha}$ ) recorded the maximum seed yield (20.8 $\mathrm{q} / \mathrm{ha}$ ) and increase was $11.8 \%$ over control. This may be due to increase the yield attributes character with application of fly ash resulted in more mustard seed yield. Amongst the different nitrogen levels, the maximum seed yield (26.0 q/ha) and increase the seed yield was 45.6, 24.2, $17.4 \%$ over control, 75 and $100 \mathrm{~kg} \mathrm{~N} / \mathrm{ha}$ but it was statically at par with treatment $100 \mathrm{~kg} \mathrm{~N} / \mathrm{ha}$. This might be due to increasing in no. of siliqua/plant and no. of seeds/siliqua with adequate nitrogen supply to plants. Ram et al., (2013) reported that application of $\mathrm{N} 120 \mathrm{~kg} / \mathrm{ha}$ obtained significantly higher seed yield of mustard. Similarly, Patil et al., (1996) reported that application of fly ash @ 20 t/ha along with recommended dose of fertilizers increased the seed yield of sunflower. The interaction effect between fly and nitrogen levels on seed yield of Indian mustard was also found to be nonsignificant effect. Application of Fly ash and nitrogen significantly influenced the stover yield of Indian mustard. Application of fly ash (10 t/ha) recorded the maximum stover yield (74.2 q/ha) and increase was $7.8 \%$ over control. Amongst the different nitrogen levels, the maximum stover yield (80.6 q/ha) and increase 20.8, 11.7, 5.9\% over control, 75 and $100 \mathrm{~kg} \mathrm{~N} / \mathrm{ha}$. This might be due to increasing in plant height, leaf area index and dry matter accumulation with adequate nitrogen supply to plants. Ram et al., (2013) reported that application of $120 \mathrm{~kg}$ N/ha obtained significantly higher stover yield of mustard. The interaction effect between fly and nitrogen levels on stover yield of Indian mustard was also found to be non-significant effect. The data related to harvest index presented in table 3 . The data clearly showed that application of fly ash showed nonsignificantly effect on harvest index of Indian mustard. Application of nitrogen and the interaction effect between fly and nitrogen levels on harvest index of Indian mustard was also found to be non-significant effect.

Based on the above results, the following conclusion are drawn. Application of fly ash @ 10t/ha significantly increased the growth and yield attributes of Indian mustard and gave $11.8 \%$ higher seed yield over control. The Nitrogen application significantly increased the growth and yield attributes resulting percent increased in seed yield to the extent of 45.6, 24.2, $17.4 \%$ over control 75, $100 \mathrm{~kg}$ N/ha but it was statically at par with treatment $100 \mathrm{kgN} / \mathrm{ha}$. The combined application of fly ash @ 10t/ha in 
combination with $125 \mathrm{Kg} \mathrm{N} / \mathrm{ha}$ give maximum seed yield (26.0 q/ha) But showed non- significant effect on seed yield.

\section{References}

Anonymous (2016) Executive summary rapeseed - mustard crop survey 201617.

Anonymous (2019) Executive summary rapeseed - mustard crop survey 2019.

Bhari, N R, Siag, R K and Mann, P S (2000) Response of Indian mustard (Brassica juncea $\mathrm{L}$ ) to nitrogen and phosphorus.

Jambagi, A M, Patil, C V, Yeledhalli, A N and Prakash, S S (1995) Growth and yield of sunflower grown on fly ash amended soil. In abstract National seminar on use of lignite fly ash in agriculture, Annamalainagar. pp. 232236

Kene D R, Hanjewar S A, Ingaole B M and Chapale S D (1991) effect of application of fly ash on physicchemical properties of soil. Journal of Soils and Crops 1(1):11-18.

Kuchanwar O D, Matte D B and Kene D R (1997) evaluation of graded doses of fly ash and fertilizers on nutrient content and uptake of groundnut grown on vertisols. Journal of Soils and Crops 7(1):1-3.

Narang R S and Singh S (1985) Nitrogen management in Indian mustard. Indian Journal of Agronomy 30: 477-82.

Patil, E V, Math, K K, Bulbule, A V, Prakash, S S and Yeledhalli, N.A. (1996) Effects of fly ash on soil crust strength and crop yield. Journal of Maharashtra Agriculture University 21(1): 9-11.

Ram, Hardev, Yadav, D S and Jat, R D (2013) Effect of nutrient management on growth, yield attributes and yield of Indian mustard. Annals of Agriculture Bio Research 18(2):132-134.

Singh P C (2002) Effect of different levels of nitrogen and phosphorus on yield, yield components and oil content of mustard (Brassica juncea L.) Journal of Living World 9: 1-4.

Thanunathan, K, Imayavarambarn, V, Singaravel, $\mathrm{R}$ and Kandasamy, $\mathrm{S}$. (2001) Effect of fly ash on growth, yield and nutrient uptake of sesame. Sesame and Safflower Newslett., 16:42-45.'

\section{How to cite this article:}

Harmohan Singh, Balwinder Singh Dhillon and Mandeep Kaur. 2020. Effect of Different Fly Ash and Nitrogen Levels on Growth and Yield of Indian Mustard (Brassica juncea L.). Int.J.Curr.Microbiol.App.Sci. 9(12): 2057-2062. doi: https://doi.org/10.20546/ijcmas.2020.912.242 